\title{
Extraction socket preservation
}

\author{
Young-Kyun Kim, DDS, PhD ${ }^{1,2,3}$, Jeong-Kui Ku, DDS, PhD, FIBCOMS $S^{4,5}$ \\ ${ }^{1}$ Editor-in-Chief of J Korean Assoc Oral Maxillofac Surg, ${ }^{2}$ Department of Oral and Maxillofacial Surgery, Section of Dentistry, Seoul \\ National University Bundang Hospital, Seongnam, ${ }^{3}$ Department of Dentistry \& Dental Research Institute, School of Dentistry, Seoul \\ National University, Seoul, ${ }^{4}$ Section Editor of J Korean Assoc Oral Maxillofac Surg, ${ }^{5}$ Department of Oral and Maxillofacial Surgery, \\ Section of Dentistry, Armed Forces Capital Hospital, Armed Forces Medical Command, Seongnam, Korea
}

\begin{abstract}
J Korean Assoc Oral Maxillofac Surg 2020;46:435-439)
Extraction socket preservation (ESP) is widely performed after tooth extraction for future implant placement. For successful outcome of implants after extractions, clinicians should be acquainted with the principles and indications of ESP. It is recommended that ESP be actively implemented in cases of esthetic areas, severe bone defects, and delayed implant placement. Dental implant placement is recommended at least 4 months after ESP.
\end{abstract}

Key words: Dental implant, Tooth extraction, Socket graft

[paper submitted 2020. 11. 10 / accepted 2020. 11. 10]

\section{Introduction}

Tooth extraction triggers disuse atrophy of the surrounding alveolar bone. Within 1 year of extraction, an average of $50 \%$ of the ridge width is reduced. The average amount of loss was between $5-7 \mathrm{~mm}$, and $2 / 3$ of this reduction occurred within the first 3 months and showed similar patterns in all areas of the oral cavity ${ }^{1}$. Since maxillary buccal cortical bone resorption occurs after extraction, the center of maxillary ridge is moved toward the palatal side. Maxillary buccal resorption is more pronounced in molars compared to anterior and premolar areas, and mandibular buccal resorption occurs more frequently than that of the lingual bone ${ }^{2}$. In 2009, a systemic review demonstrated bone resorption of approximately $3.87 \mathrm{~mm}$ and 1.67 $\mathrm{mm}$ horizontally and vertically, respectively, during the first three months after extraction ${ }^{3}$. In 2012, another randomized controlled trial revealed that more than $60 \%$ of the total re-

\section{Young-Kyun Kim}

Department of Oral and Maxillofacial Surgery, Section of Dentistry, Seoul National University Bundang Hospital, 82 Gumi-ro 173beon-gil, Bundanggu, Seongnam 13620, Korea

TEL: +82-31-787-7541 FAX: +82-31-787-4068

E-mail:kyk0505@snubh.org

ORCID: https://orcid.org/0000-0002-7268-3870

(c) This is an open-access article distributed under the terms of the Creative Commons Attribution Non-Commercial License (http://creativecommons.org/ licenses/by-nc/4.0/), which permits unrestricted non-commercial use, distribution, and reproduction in any medium, provided the original work is properly cited.

Copyright (C) 2020 The Korean Association of Oral and Maxillofacial Surgeons. All rights reserved. sorption occurred during the first six months after tooth loss ${ }^{4}$.

Since disuse atrophy persists if not restored, many issues with vertical and horizontal bone loss can occur. Additional bone graft surgeries are inevitable for dental implant treatment in areas of bone loss. To minimize bone loss, extraction socket preservation (ESP) has been introduced, where bone graft is performed at the time of extraction. However, the efficacy of ESP has been controversial, and the procedure might be unnecessary in some cases. At the time of extraction, the clinician should make a decision based on the condition of the extraction socket and surrounding tissues ${ }^{5}$. Extraction sockets can be classified into four types according to degree of bone loss, on which need for ESP can depend.(Table 1) Alveolar ridge preservation and post-extraction preservation of the socket are used synonymously with $\mathrm{ESP}^{6,7}$.

\section{Controversy regarding ESP}

\section{Positive view}

Since ESP is performed to minimize ridge atrophy after tooth extraction, several advantages have been suggested, including that ESP reduces the need for additional bone graft, facilitates the implant procedure, and improves marginal bone loss and survival/success rate of implants ${ }^{8}$. Avila-Ortiz et al. ${ }^{9}$ reported that the ESP group had statistically significantly less bone resorption of $1.89 \mathrm{~mm}$ horizontally, $2.07 \mathrm{~mm}$ 
Table 1. Classification of extraction sockets ${ }^{6,7}$

\begin{tabular}{cc}
\hline Class & Description \\
\hline I & 4-wall defect, intact bony housing, no wall involvement \\
II & 3-wall defect, 3 intact walls, 1 wall with dehiscence or \\
& fenestration \\
III & Type 1: adequate height, inadequate width \\
& Type 2: 2 intact walls, 2 walls with dehiscence or \\
& fenestration \\
IV & 1-wall defect, inadequate vertical height, inadequate horiz \\
& ontal width
\end{tabular}

Young-Kyun Kim et al: Extraction socket preservation. J Korean Assoc Oral Maxillofac Surg 2020

at labial side and $1.18 \mathrm{~mm}$ at lingual side vertically compared to the simple extraction group. In particular, the result of ESP was excellent in the maxilla. When ESP is performed in the maxillary posterior region, sinus elevation surgery can be minimized or avoided, enabling flapless implant surgery ${ }^{10}$.

Natural bone healing is insufficient in extraction sockets with periodontal or inflammatory disease because soft tissue invasion into the socket impedes bone healing even long after the procedure. To maintain the volume of the extraction socket, thickness of the buccal bone wall is the most important factor. ESP is generally recommended for sockets with thin buccal bone wall $(\leq 1 \mathrm{~mm})$ to compensate for bone resorption with suggested non-absorbable bone substitutes such as deproteinized bovine bone and alloplastic bone ${ }^{11-13}$.

\section{Negative view}

Some researchers have argued a negative view of $\mathrm{ESP}^{8,14,15}$. ESP can reduce the bone resorption, but not completely prevent. Rather, bone substitutes could contribute to impaired natural bone healing. No differences has been reported in feasibility, success/survival rates, and marginal bone loss between implants with and without $\mathrm{ESP}^{8,14,15}$. Simon et al. ${ }^{16}$ questioned the usefulness of performing bone graft before implant placement (guided bone regeneration [GBR], ESP) and observed that bone height loss occurred more than bone width even after bone graft. Therefore, it was argued that filling the graft material not only inside the extraction socket but also outside the extraction socket and covering it with a barrier membrane could prevent bone loss as much as possible.

\section{Surgical Technique of ESP}

Complete removal of inflammatory tissue and pathologic lesions should be performed with minimally invasive procedures after tooth extraction. All soft tissues along the socket wall are removed, and spontaneous bleeding is induced to release healing factors from the bone marrow. Suturing is performed with a collagen plug, barrier membrane, or autogenous gingival tissue after application of bone substitute. Primary wound closure is not essential if proper suturing is achieved to prevent dislodgement of the membrane or collagen plug above the substitutes. It was said that using a osteoconductive bone substitutes such as deproteinized bovine bone material (DBBM) (Bio-Oss; Geistlich Pharma AG, Wolhusen, Switzerland) or other synthetic materials with slow resorption and covering the upper part with a resorbable barrier membrane or connective tissue (CT) graft, or selecting the BioCol procedure maintains the volume of the extraction socket well and facilitates implant placement in the future ${ }^{5}$. Implants were placed with no complications at 4-6 months after grafting.

\section{Bone Graft Materials}

\section{Autogenous bone}

In 2005, an ESP case with autogenous bone was reported using the buccal bone of the maxillary canine and raising a rotated palatal flap ${ }^{17}$. However, autogenous bone has not been widely used due to its high risk of resorption.

\section{Xenogeneic bone}

Currently, xenografts are generally used in implant dentistry including anorganic bovine bone and porcine bone. Artzi et al. ${ }^{18}$ reported $82.3 \%$ extraction socket filling with new bone at 9 months after ESP using porous bovine bone mineral (PBBM). PBBM is a biocompatible and acceptable bone substitute for ESP that shows no resorption for 9 months ${ }^{19}$. In 2018, deproteinized porcine bone mineral (DPBM) exhibited comparable ESP outcomes with $\mathrm{DBBM}^{20}$.

\section{Synthetic bone}

Several synthetic bone products have been reported to have effective outcomes on ESP, including Bioplant HTR ${ }^{9,21}$, hydroxyapatite $(\mathrm{HA})^{22}$, biphasic calcium phosphate $(\mathrm{BCP})^{23,24}$, bioactive glass ${ }^{25}$, and calcium sulfate ${ }^{25}$.

\section{Allogeneic bone}

Allogeneic bone, such as freeze-dried bone allograft, has been widely used in implant dentistry ${ }^{26}$. To improve the bone healing potential and reduce the mobility of bone graft, allo- 
geneic bone can be manufactured as putty or gel type and can be mixed with particulate xenogeneic or synthetic bone ${ }^{27}$.

\section{Growth factors}

Ridge preservation and bony healing can be enhanced with growth factors including recombinant human bone morphogenetic protein-2 (rhBMP-2), platelet concentrate (plateletrich plasma [PRP], platelet-rich fibrin [PRF]), synthetic cellbinding peptide P-15 (Putty P15), and vascular endothelial growth factor (VEGF) $)^{28-36}$.

\section{Socket Sealing}

After packing the socket with bone substitute, it is recommended to cover it with a membrane. To perform minimally invasive surgery, flap release such as vertical releasing incisions and submucosal undermining should be avoided as much as possible.

\section{Autogenous tissue}

Since 1997, socket sealing surgery has been used to cover the graft with free gingival tissue or CT from the palate or maxillary tuberosity ${ }^{36-40}$.

\section{Acellular dermal matrix}

Luczyszyn et al. ${ }^{41}$ introduced a technique using an acellular dermal matrix to cover the socket graft with resorbable HA. The HA affected the ESP outcome, and the matrix contributed to thickening of the soft tissue around the socket.

\section{Resorbable barrier membrane}

Although many researchers have demonstrated significant ESP outcomes using only a resorbable membrane to cover the socket, without bone grafting, the outcome could be maximized with bone grafting ${ }^{41-43}$. In cases of BCP grafting with a cross-linked collagen membrane, sufficient ridge preservation occurred with prolonged barrier function even with early membrane exposure ${ }^{44,45}$. Acceptable ESP outcomes were reported with polylactide and polyglycolide sponges and native bilayer collagen membranes ${ }^{46,47}$.

\section{Non-resorbable barrier membrane}

Faciola Pessôa de Oliveira et al ${ }^{48}$ reported successful ESP outcomes after covering with a polytetrafluoroethelne (dPTFE) membrane after minimally traumatic extraction.

\section{Collagen sponge}

The Bio-Col method was suggested as an effective ESP technique to pack a collagen sponge above the xenogeneic bone graft into $1 / 2$ to $2 / 3$ of the extraction socket ${ }^{49,50}$.

\section{Timing of Implant Placement after ESP}

Several histologic studies have been conducted on ESP with bone graft ${ }^{51,52}$. Although ESP contributed to prevention of bone resorption, some cases exhibited insufficient bone healing quantity and quality. Larger defects required longer healing time ${ }^{53}$. New bone grew at the contact with recipient bone up to the lower $1 / 3$ of the defect. Bone regeneration to the upper aspect required a long healing period ${ }^{54,55}$. Therefore, implant placement was recommended after a sufficient healing period of approximately 4 months ${ }^{51,52,56}$. Primary stability of the implant should be obtained at the basal bone rather than in the bone graft area.

\section{Summary}

1. ESP is not required in all extraction cases, but should be considered in the following cases:

1) Aesthetic concern

2) Severe destruction of residual bone walls after tooth extraction

3) Delayed implant treatment

2. With ESP, the necessity for additional bone grafting is reduced at implant placement.

3. ESP does not affect the success rate or marginal bone loss of implants.

4. No consensus has been made on the standard protocol among ESP techniques.

5. Socket sealing can protect bone substitutes and contribute to soft tissue healing through autogenous gingival tissues, barrier membranes, collagen sponges, etc.

6. During ESP, primary closure is not essential, but minimally traumatic procedures are very important.

7. Dental implants are recommended to be placed 4 months after ESP.

\section{ORCID}

Young-Kyun Kim, https://orcid.org/0000-0002-7268-3870 
Jeong-Kui Ku, https://orcid.org/0000-0003-1192-7066

\section{Authors' Contributions}

Y.K.K. participated in the literature review and wrote the primary manuscript. J.K.K. participated in the literature review and wrote the final manuscript.

\section{Conflict of Interest}

No potential conflict of interest relevant to this article was reported.

\section{References}

1. Schropp L, Wenzel A, Kostopoulos L, Karring T. Bone healing and soft tissue contour changes following single-tooth extraction: a clinical and radiographic 12-month prospective study. Int J Periodontics Restorative Dent 2003;23:313-23.

2. Pietrokovski J, Massler M. Alveolar ridge resorption following tooth extraction. J Prosthet Dent 1967;17:21-7. https://doi. org/10.1016/0022-3913(67)90046-7

3. Van der Weijden F, Dell'Acqua F, Slot DE. Alveolar bone dimensional changes of post-extraction sockets in humans: a systematic review. J Clin Periodontol 2009;36:1048-58. https://doi. org/10.1111/j.1600-051X.2009.01482.x

4. Hämmerle CHF, Jung RE, Sanz M, Chen S, Martin WC, Jackowski $\mathrm{J}$; this multicenter study group, et al. Submerged and transmucosal healing yield the same clinical outcomes with two-piece implants in the anterior maxilla and mandible: interim 1-year results of a randomized, controlled clinical trial. Clin Oral Implants Res 2012;23:211-9. https://doi.org/10.1111/j.1600-0501.2011.02210.x

5. Darby I, Chen S, De Poi R. Ridge preservation: what is it and when should it be considered. Aust Dent J 2008;53:11-21. https://doi. org/10.1111/j.1834-7819.2007.00008.x

6. Castellon P, Yukna RA. Immediate dental implant placement in sockets augmented with HTR synthetic bone. Implant Dent 2004;13:42-8. https://doi.org/10.1097/01.id.0000116451.04676.7b

7. Meltzer AM. Non-resorbable-membrane-assisted bone regeneration: microscrews, microplates, and reinforcement--part II. Dent Implantol Update 1995;6:53-6.

8. Mardas N, Trullenque-Eriksson A, MacBeth N, Petrie A, Donos $\mathrm{N}$. Does ridge preservation following tooth extraction improve implant treatment outcomes: a systematic review: group 4: therapeutic concepts \& methods. Clin Oral Implants Res 2015;26 Suppl 11:180-201. https://doi.org/10.1111/clr.12639

9. Avila-Ortiz G, Elangovan S, Kramer KW, Blanchette D, Dawson DV. Effect of alveolar ridge preservation after tooth extraction: a systematic review and meta-analysis. J Dent Res 2014;93:950-8. https://doi.org/10.1177/0022034514541127

10. Cha JK, Song YW, Park SH, Jung RE, Jung UW, Thoma DS. Alveolar ridge preservation in the posterior maxilla reduces vertical dimensional change: a randomized controlled clinical trial. Clin Oral Implants Res 2019;30:515-23. https://doi.org/10.1111/clr.13436

11. Tomasi C, Donati M, Cecchinato D, Szathvary I, Corrà E, Lindhe J. Effect of socket grafting with deproteinized bone mineral: an RCT on dimensional alterations after 6 months. Clin Oral Implants Res 2018;29:435-42. https://doi.org/10.1111/clr.13141

12. Mahesh L, Venkataraman N, Shukla S, Prasad H, Kotsakis GA. Alveolar ridge preservation with the socket-plug technique utiliz- ing an alloplastic putty bone substitute or a particulate xenograft: a histological pilot study. J Oral Implantol 2015;41:178-83. https:// doi.org/10.1563/AAID-JOI-D-13-00025

13. Ku JK, Hong I, Lee BK, Yun PY, Lee JK. Dental alloplastic bone substitutes currently available in Korea. J Korean Assoc Oral Maxillofac Surg 2019;45:51-67. https://doi.org/10.5125/jkaoms.2019.45.2.51

14. Kivovics M, Szabó BT, Németh O, Tari N, Dőri F, Nagy P, et al. Microarchitectural study of the augmented bone following ridge preservation with a porcine xenograft and a collagen membrane: preliminary report of a prospective clinical, histological, and micro-computed tomography analysis. Int J Oral Maxillofac Surg 2017;46:250-60. https://doi.org/10.1016/j.ijom.2016.10.010

15. Horváth A, Mardas N, Mezzomo LA, Needleman IG, Donos N. Alveolar ridge preservation. A systematic review. Clin Oral Investig 2013;17:341-63. https://doi.org/10.1007/s00784-012-0758-5

16. Simon BI, Von Hagen S, Deasy MJ, Faldu M, Resnansky D. Changes in alveolar bone height and width following ridge augmentation using bone graft and membranes. J Periodontol 2000;71:1774-91. https://doi.org/10.1902/jop.2000.71.11.1774

17. Peñarrocha M, García-Mira B, Martinez O. Localized vertical maxillary ridge preservation using bone cores and a rotated palatal flap. Int J Oral Maxillofac Implants 2005;20:131-4.

18. Artzi Z, Tal H, Dayan D. Porous bovine bone mineral in healing of human extraction sockets. Part 1: histomorphometric evaluations at 9 months. J Periodontol 2000;71:1015-23. https://doi.org/10.1902/ jop.2000.71.6.1015

19. Artzi Z, Tal H, Dayan D. Porous bovine bone mineral in healing of human extraction sockets: 2 . histochemical observations at 9 months. $\mathrm{J}$ Periodontol 2001;72:152-9. https://doi.org/10.1902/jop.2001.72.2.152

20. Lee JS, Cha JK, Kim CS. Alveolar ridge regeneration of damaged extraction sockets using deproteinized porcine versus bovine bone minerals: a randomized clinical trial. Clin Implant Dent Relat Res 2018;20:729-37. https://doi.org/10.1111/cid.12628

21. Ashman A, Lopinto J. Placement of implants into ridges grafted with bioplant HTR synthetic bone: histological long-term case history reports. J Oral Implantol 2000;26:276-90. https://doi. org/10.1563/1548-1336(2000)026<0276:POIIRG >2.3.CO;2

22. Rothamel D, Schwarz F, Herten M, Engelhardt E, Donath K, Kuehn P, et al. Dimensional ridge alterations following socket preservation using a nanocrystalline hydroxyapatite paste: a histomorphometrical study in dogs. Int J Oral Maxillofac Surg 2008;37:7417. https://doi.org/10.1016/j.ijom.2008.04.017

23. Patel K, Mardas N, Donos N. Radiographic and clinical outcomes of implants placed in ridge preserved sites: a 12-month post-loading follow-up. Clin Oral Implants Res 2013;24:599-605. https:// doi.org/10.1111/j.1600-0501.2012.02500.x

24. Boix D, Weiss P, Gauthier O, Guicheux J, Bouler JM, Pilet P, et al. Injectable bone substitute to preserve alveolar ridge resorption after tooth extraction: a study in dog. J Mater Sci Mater Med 2006;17:1145-52. https://doi.org/10.1007/s10856-006-0542-7

25. Camargo PM, Lekovic V, Weinlaender M, Klokkevold PR, Kenney $\mathrm{EB}$, Dimitrijevic B, et al. Influence of bioactive glass on changes in alveolar process dimensions after exodontia. Oral Surg Oral Med Oral Pathol Oral Radiol Endod 2000;90:581-6. https://doi. org/10.1067/moe.2000.110035

26. Iasella JM, Greenwell H, Miller RL, Hill M, Drisko C, Bohra AA, et al. Ridge preservation with freeze-dried bone allograft and a collagen membrane compared to extraction alone for implant site development: a clinical and histologic study in humans. J Periodontol 2003;74:990-9. https://doi.org/10.1902/jop.2003.74.7.990

27. Vance GS, Greenwell H, Miller RL, Hill M, Johnston H, Scheetz JP. Comparison of an allograft in an experimental putty carrier and a bovine-derived xenograft used in ridge preservation: a clinical and histologic study in humans. Int J Oral Maxillofac Implants 2004;19:491-7.

28. Huh JB, Lee HJ, Jang JW, Kim MJ, Yun PY, Kim SH, et al. Ran- 
domized clinical trial on the efficacy of Escherichia coli-derived rhBMP-2 with $\beta$-TCP/HA in extraction socket. J Adv Prosthodont 2011;3:161-5. https://doi.org/10.4047/jap.2011.3.3.161

29. Shi B, Zhou Y, Wang YN, Cheng XR. Alveolar ridge preservation prior to implant placement with surgical-grade calcium sulfate and platelet-rich plasma: a pilot study in a canine model. Int J Oral Maxillofac Implants 2007;22:656-65.

30. Kim YS, Kwon KH, Cha SY, Min SK. Effect of gelatin spongy and platelet rich plasma on ridge preservation and bone formation after extraction. J Korean Assoc Maxillofac Plast Reconstr Surg 2005;27:238-47.

31. Ustaoğlu G, Göller Bulut D, Gümüş KÇ. Evaluation of different platelet-rich concentrates effects on early soft tissue healing and socket preservation after tooth extraction. J Stomatol Oral Maxillofac Surg 2020;121:539-44. https://doi.org/10.1016/ j.jormas.2019.09.005

32. Areewong K, Chantaramungkorn M, Khongkhunthian P. Plateletrich fibrin to preserve alveolar bone sockets following tooth extraction: a randomized controlled trial. Clin Implant Dent Relat Res 2019;21:1156-63. https://doi.org/10.1111/cid.12846

33. Ahmed N, Gopalakrishna V, Shetty A, Nagraj V, Imran M, Kumar P. Efficacy of PRF vs PRF + biodegradable collagen plug in post-extraction preservation of socket. J Contemp Dent Pract 2019;20:1323-8.

34. Canellas JVDS, da Costa RC, Breves RC, de Oliveira GP, Figueredo CMDS, Fischer RG, et al. Tomographic and histomorphometric evaluation of socket healing after tooth extraction using leukocyteand platelet-rich fibrin: a randomized, single-blind, controlled clinical trial. J Craniomaxillofac Surg 2020;48:24-32. https://doi. org/10.1016/j.jcms.2019.11.006

35. Neiva RF, Tsao YP, Eber R, Shotwell J, Billy E, Wang HL. Effects of a putty-form hydroxyapatite matrix combined with the synthetic cell-binding peptide P-15 on alveolar ridge preservation. J Periodontol 2008;79:291-9. https://doi.org/10.1902/jop.2008.070038

36. Keith JD Jr, Salama MA. Ridge preservation and augmentation using regenerative materials to enhance implant predictability and esthetics. Compend Contin Educ Dent 2007;28:614-21; quiz 622-4.

37. Landsberg CJ. Implementing socket seal surgery as a socket preservation technique for pontic site development: surgical steps revisited--a report of two cases. J Periodontol 2008;79:945-54. https://doi.org/10.1902/jop.2008.070298

38. Misch CE, Dietsh-Misch F, Misch CM. A modified socket seal surgery with composite graft approach. J Oral Implantol 1999;25:24450. https://doi.org/10.1563/1548-1336(1999)025<0244:AMSSSW $>2.3 . \mathrm{CO} ; 2$

39. Karaca Ç, Er N, Gülşahı A, Köseoğlu OT. Alveolar ridge preservation with a free gingival graft in the anterior maxilla: volumetric evaluation in a randomized clinical trial. Int J Oral Maxillofac Surg 2015;44:774-80. https://doi.org/10.1016/j.ijom.2015.01.015

40. Tal H. Autogenous masticatory mucosal grafts in extraction socket seal procedures: a comparison between sockets grafted with demineralized freeze-dried bone and deproteinized bovine bone mineral. Clin Oral Implants Res 1999;10:289-96. https://doi.org/10.1034/ j.1600-0501.1999.100405.x

41. Luczyszyn SM, Papalexiou V, Novaes AB Jr, Grisi MF, Souza SL, Taba M Jr. Acellular dermal matrix and hydroxyapatite in prevention of ridge deformities after tooth extraction. Implant Dent 2005;14:176-84. https://doi.org/10.1097/01. id.0000165082.77499.41

42. Lekovic V, Camargo PM, Klokkevold PR, Weinlaender M, Kenney EB, Dimitrijevic B, et al. Preservation of alveolar bone in extraction sockets using bioabsorbable membranes. J Periodontol 1998;69:1044-9. https://doi.org/10.1902/jop.1998.69.9.1044

43. Nunes FAS, Pignaton TB, Novaes AB Jr, Taba M Jr, Messora MR, Palioto DB, et al. Evaluation of a bone substitute covered with a collagen membrane for ridge preservation after tooth extraction. Clini- cal and tomographic randomized controlled study in humans. Clin Oral Implants Res 2018;29:424-33. https://doi.org/10.1111/clr.13140 44. Kim DM, De Angelis N, Camelo M, Nevins ML, Schupbach $\mathrm{P}$, Nevins M. Ridge preservation with and without primary wound closure: a case series. Int J Periodontics Restorative Dent 2013;33:71-8. https://doi.org/10.11607/prd.1463

45. Oh TJ, Meraw SJ, Lee EJ, Giannobile WV, Wang HL. Comparative analysis of collagen membranes for the treatment of implant dehiscence defects. Clin Oral Implants Res 2003;14:80-90. https:// doi.org/10.1034/j.1600-0501.2003.140111.x

46. Serino G, Biancu S, Iezzi G, Piattelli A. Ridge preservation following tooth extraction using a polylactide and polyglycolide sponge as space filler: a clinical and histological study in humans. Clin Oral Implants Res 2003;14:651-8. https://doi.org/10.1034/j.16000501.2003.00970.x

47. Jung RE, Sapata VM, Hämmerle CHF, Wu H, Hu XL, Lin Y. Combined use of xenogeneic bone substitute material covered with a native bilayer collagen membrane for alveolar ridge preservation: a randomized controlled clinical trial. Clin Oral Implants Res 2018;29:522-9. https://doi.org/10.1111/clr.13149

48. Faciola Pessôa de Oliveira PG, Pedroso Bergamo ET, Bordin D, Arbex L, Konrad D, Gil LF, et al. Ridge architecture preservation following minimally traumatic exodontia techniques and guided tissue regeneration. Implant Dent 2019;28:319-28. https://doi. org/10.1097/ID.0000000000000886

49. Kim YK, Yun PY, Lee HJ, Ahn JY, Kim SG. Ridge preservation of the molar extraction socket using collagen sponge and xenogeneic bone grafts. Implant Dent 2011;20:267-72. https://doi.org/10.1097/ ID.0b013e3182166afc

50. Kim JW, Jeon HR, Hong JR. The study on ridge preservation for implant site development. J Korean Assoc Oral Maxillofac Surg 2006;32:430-5.

51. Koo TH, Song YW, Cha JK, Jung UW, Kim CS, Lee JS. Histologic analysis following grafting of damaged extraction sockets using deproteinized bovine or porcine bone mineral: a randomized clinical trial. Clin Oral Implants Res 2020;31:93-102. https://doi. org/10.1111/clr.13557

52. Koo TH, Choe SH, Kim S, Kim CS, Lee JS. Histologic biopsy results from extraction socket grafting by deproteinized bovine or porcine bone mineral in damaged extraction sockets- randomized controlled clinical trial. Clin Oral Implant Res 2019;30:33-4. https://doi.org/10.1111/clr.55_13508

53. Im SU, Hong JY, Chae GJ, Jung UW, Kim CS, Lee YK, et al. The evaluation of healing patterns in surgically created circumferential gap defects around dental implants according to implant surface, defect width and defect morphology. J Korean Acad Periodontol 2008;38:385-94

54. Wang HL, Kiyonobu K, Neiva RF. Socket augmentation: rationale and technique. Implant Dent 2004;13:286-96. https://doi. org/10.1097/01.id.0000148559.57890.86

55. Heberer S, Al-Chawaf B, Jablonski C, Nelson JJ, Lage H, Nelson $\mathrm{K}$. Healing of ungrafted and grafted extraction sockets after 12 weeks: a prospective clinical study. Int J Oral Maxillofac Implants 2011;26:385-92

56. Haghighat A, Hekmatian E, Abdinian M, Sadeghkhani E. Radiographic evaluation of bone formation and density changes after mandibular third molar extraction: a 6 month follow up. Dent Res J (Isfahan) 2011;8:1-5.

How to cite this article: Kim YK, Ku JK. Extraction socket preservation. J Korean Assoc Oral Maxillofac Surg 2020;46:435-439. https://doi.org/10.5125/jkaoms.2020.46.6.435 